\title{
COCONUT LEAF NUTRIENT LEVELS OF BEARING DWARF VARIETIES AND PHYSIOLOGICAL CRITICAL AND ADEQUACY LEVELS IN CROP NUTRITION MANAGEMENT
}

\author{
By
}

\author{
Severino S. Magat
}

\begin{abstract}
An analysis of the leaf nutrient concentrations data of bearing palms (grown in a suitable coastal ecosystem) of three coconut dwarf varieties [Malayan yellow dwarf(MLYD), Catigan green dwarf(CATGD) and Tacunan green dwarf(TACGD)] planted at the designed-genetic blocks of the Zamboanga Research Center, San Ramon, Zamboanga City (Western Mindanao, Philippines), covering the period 1995-1999, was conducted. The variability and trend of each leaf nutrient (N, P, K, Ca, $\mathrm{Mg}, \mathrm{Na}, \mathrm{Cl}, \mathrm{S}$ and $\mathrm{B})$ over the years was determined.

The critical levels of leaf nutrients are estimated based on the average or normal values of the historical data. An initial general reference guide on the physiological leaf critical levels of dwarfs is presented, as follows (leaf \#14, dry matter): $1.70 \% \mathrm{~N}: 0.125 \% \mathrm{P} ; 0.90 \% \mathrm{~K} ; 0.38 \% \mathrm{Ca} ; 0.26 \% \mathrm{Mg}$; ; $0.12 \% \mathrm{Na}, 0.37 \% \mathrm{Cl} ; 0.15 \% \mathrm{~S}$; and $11 \mathrm{ppm} \mathrm{B}$.
\end{abstract}

The implications of knowing the adequacy and critical levels in leaves as an indicator of crop nutrition to optimize the yield potential of dwarf varieties of coconut are discussed.

\section{INTRODUCTION}

In recent years, globally, there have been increasing concerns to improve the plantings, young tender nut supply, and productivity of dwarf varieties for commercial purposes - largely intended for food, nutritional and medicinal purposes (Eyzaguirre,1996; Naka, 1996; Thampan, 1996; Wazir and Othman, 1996; Ovasuru, 1996). In the varietal improvement (development of improved planting materials and production of hybrids of the dwarf $x$ tall crosses), dwarf varieties have been collected, conserved, managed and utilized for new planting, and replanting and rehabilitation objectives (Thampan, 1996; Peries, 1996; Novarianto and Santos, 1996; Ovasuru, 1996).
Generally, dwarf coconut varieties are characteristically: shorter and slow in growth; with slender stem; having smaller leaves, inflorescences and fruit (with exception of some green dwarfs); precocious and rapid succession of inflorescences; and with high degree of selfpollination (Ohler and Magat, 2001). Dwarfs are differentiated based also on the color of the leaf petiole (normally same as the skin color of immature nuts). For instance, in most coconutproducing countries, there are green dwarfs, yellow dwarfs and red dwarfs (or orange dwarfs). Among the green dwarfs, ones popular in the Philippines are the Catigan green dwarf (CATGD); Tacunan green dwarf (TACGD) and Aromatic green dwarf (AROGD), claimed to have originated from Thailand.

$1 /$ Career Scientist IV, Dept. of Agriculture/Philippine Coconut Authority, Research, Development and Extension Branch, Quezon City, Philippines. 
In the Philippines and rest of coconutproducing countries, to optimize the productivity (yield) and production volume from these varieties, crop nutrition management is essential, as most coconut areas now have nutritionally-deficient, degraded and marginal soils.

To determine the crop and locationspecific fertilizer needs of the dwarf varieties of coconut, the physiological critical nutrient levels of the leaves collected at different stages of crop development should be identified to be able to diagnose the nutrient status of the coconut trees thru the leaf analysis. For mature or bearing palms, leaf rank \# 14 has been the accepted as the reference leaf, thus usually sampled annually preferably during dry periods and submitted to analytical laboratories for the analysis of leaf nutrient concentrations ( $\mathrm{N}, \mathrm{P}, \mathrm{K}, \mathrm{Ca}, \mathrm{Mg}, \mathrm{Na}, \mathrm{Cl}, \mathrm{S}$ and $\mathrm{B})$. As practical and needed, other micronutrients ( $\mathrm{Zn}, \mathrm{Mn}, \mathrm{Fe}$ and $\mathrm{Cu}$ ) other than $\mathrm{B}$ are also included in the analysis.

\section{DATA OF SELECTED DWARF VARIETIES}

Three dwarf varieties of coconut grown in genetic blocks at the Zamboanga Research Center (Philippine Coconut Authority, Department of Agriculture), at San Ramon Zamboanga City, Western Mindanao) was used in this study. The important features of the three dwarfs are as follows:

a. Malayan yellow dwarf (MLYD) - produces larger number of nuts under excellent ecological conditions; nuts contains around $150 \mathrm{~g}$ copra; petiole and young nut yellowish (Balingasa and Santos, 1978); b. Catigan green dwarf (CATGD) - produces round medium-size nut, about $210 \mathrm{~g}$ copra/nut, flowering could start 20 months from fieldplanting; full-bearing palms with copra yield of 3 t/ha/yr, but may be followed by lower yield cropping year (Santos, 1989);

c. Tacunan green dwarf (TACGD) - easily recognized with its short spikelets; shrunken spathes; medium-size nuts with long stigmatic end and bulbous base; average of $230 \mathrm{~g}$ copra per nut; claimed to be resistant to very strong winds, likely due to a strong root system (Santos, 1989)

Leaf analyses and yield data (1995 - 1999) of three selected dwarf varieties in some experimental blocks at the Zamboanga Research Center were reviewed. Relevant data are indicated in table 1.1. The rainfed center, situated in a coastal area has fair to above average soil conditions and suitable climatic conditions for coconut production. Fertilizer application mainly based on annual leaf analysis had been an annual practice, following a modern and high-yield farming production system, but rainfed (no irrigation), even during the extended dry periods (El Niño years).

Data on yield of coconut was requested from the files of the Breeding and Genetics Division of PCA-ZRC. Leaf samples submitted by the ZRC was analyzed by the Plant Tissue Analysis Laboratory, Plant and Soils Division, based at the central office of PCA, Diliman, Quezon City, Metro Manila. 


\begin{tabular}{|c|c|c|c|c|c|c|c|c|c|c|c|c|}
\hline \multicolumn{13}{|c|}{$\begin{array}{l}\text { TABLE 1.1. YIELD AND LEAF NUTRIENT STATUS OF THREE DWARF VARIETIES, } \\
\text { PCA-ZAMBOANGA RESEARCH CENTER (LEAF RANK \#14, 1995-1999)* }\end{array}$} \\
\hline \multirow{2}{*}{ VAR(1) } & \multirow{2}{*}{ YEAR } & \multicolumn{2}{|c|}{ YIELD/year } & \multicolumn{9}{|c|}{$\begin{array}{c}\text { LEAF NUTRIENT CONTENT (\%, dry matter. leaf rank } \\
\# 14)\end{array}$} \\
\hline & & \begin{tabular}{|l|} 
Nut/ \\
Tree
\end{tabular} & \begin{tabular}{|c|} 
Copra/ \\
Tree(kg)
\end{tabular} & $\mathbf{N}$ & $\mathbf{P}$ & $\mathbf{K}$ & $\mathbf{C a}$ & Mg & $\mathbf{N a}$ & Cl & $\mathbf{S}$ & $\begin{array}{c}\text { B } \\
(\mathbf{p p m})\end{array}$ \\
\hline \multirow[t]{5}{*}{$M L Y D$} & 1995 & 91 & 14.2 & 2.02 & 0.165 & 0.94 & 0.37 & 0.35 & 0.22 & 0.35 & 0.21 & 11.2 \\
\hline & 1996 & 148 & 29.1 & 2.01 & 0.138 & 0.75 & 0.38 & 0.36 & 0.20 & 0.19 & 0.17 & 10.4 \\
\hline & 1998 & 118 & 23.1 & 1.55 & 0.124 & 0.95 & 0.35 & 0.29 & 0.19 & 0.29 & 0.17 & 12.7 \\
\hline & 1999 & 166 & 30.7 & 1.72 & 0.127 & 0.62 & 0.47 & 0.34 & 0.12 & 0.38 & 0.17 & 17.1 \\
\hline & Ave. & 130 & 24.3 & 1.82 & 0.138 & 0.81 & 0.39 & 0.33 & 0.18 & 0.30 & 0.18 & 13.0 \\
\hline \multirow[t]{5}{*}{ CATGD } & 1995 & 76 & 15.3 & 1.70 & 0.145 & 1.25 & 0.34 & 0.25 & 0.13 & \begin{tabular}{|l}
0.39 \\
\end{tabular} & 0.14 & 10.6 \\
\hline & 1996 & 61 & 14.4 & 2.34 & 0.166 & 0.89 & 0.50 & 0.26 & 0.10 & 0.58 & 0.18 & 12.3 \\
\hline & 1998 & 91 & 21.6 & 1.78 & 0.142 & 1.46 & 0.38 & 0.27 & 0.12 & 0.44 & 0.17 & 11.4 \\
\hline & 1999 & 62 & 12.6 & 1.69 & 0.139 & 0.92 & 0.64 & 0.30 & 0.11 & 0.70 & 0.20 & 13.8 \\
\hline & Ave. & 72 & 15.9 & 1.88 & 0.148 & 1.10 & 0.46 & 0.27 & 0.11 & 0.52 & 0.17 & 12.0 \\
\hline \multirow[t]{5}{*}{ TACGD } & 1995 & 64 & 15.7 & 1.83 & 0.138 & 1.21 & 0.32 & 0.21 & 0.10 & 0.29 & 0.15 & 11.7 \\
\hline & 1996 & 116 & 24.9 & 1.93 & 0.142 & 1.03 & 0.39 & 0.25 & 0.07 & 0.32 & 0.16 & 12.9 \\
\hline & 1998 & 68 & 12.2 & 1.86 & 0.123 & 1.32 & 0.41 & 0.27 & 0.08 & 0.45 & 0.17 & 12.4 \\
\hline & 1999 & 93 & 23.3 & 1.66 & 0.123 & 0.81 & 0.54 & 0.27 & 0.03 & 0.57 & 0.19 & 16.1 \\
\hline & Ave. & 85 & 19.0 & 1.82 & 0.131 & 1.09 & 0.41 & 0.25 & 0.07 & 0.41 & 0.17 & 13.2 \\
\hline \multicolumn{2}{|c|}{$\begin{array}{c}\text { Mean-Dwarf } \\
\text { Varieties }\end{array}$} & 96 & 19.7 & 1.84 & 0.139 & 1.00 & 0.42 & 0.28 & 0.12 & 0.41 & 0.17 & 12.7 \\
\hline \multicolumn{13}{|c|}{$\begin{array}{l}\text { NOTE: } \\
\text { * all leaf analyses done by the Plant Tissue Analysis Laboratory, PCA Central Office, } \\
\text { Diliman, Quezon City } \\
\text { (1) MLYD - Malayan yellow dwarf variety; CATGD - Catigan green dwarf; } \\
\text { TACGD - Tacunan green dwarf variety }\end{array}$} \\
\hline
\end{tabular}




\section{RESULTS AND DISCUSSION}

\subsection{Yield}

In table 1.1 , it is shown that the productivity (or yield) of dwarf varieties varied or fluctuated over the years, with nut and copra yields of the yellow dwarf (MLYD) generally higher than the two green dwarfs (TACGD and CATGD). Between the two green dwarfs, The TACGD achieved higher average yields during the evaluated cropping period of 1995 - 1999. multilocation tests which revealed clearly that CFEs (CFEn and CFEc) of dwarf $x$ tall hybrids generally higher than tall varieties over a period of 9 years from field-planting (Magat, 1966).

\subsection{Leaf Nutrient Levels}

The data presented in table 1.1 appears adequate enough to initially generate some relevant information on the physiological leaf nutrient levels as: (1) normal or adequacy levels; (2) critical levels, of dwarf varieties of

\section{Table 1.2 Average Crop Fertilizer Use Efficiency index (CFE) of three dwarf varieties of coconut grown at the PCA - Zamboanga Research Center ((period 1995-99)}

\begin{tabular}{|c|c|l|l|l|c|}
\hline $\begin{array}{l}\text { Dwarf } \\
\text { Variety }\end{array}$ & Nut/tree/yr & $\begin{array}{l}\text { Copra/tree/yr } \\
(\mathbf{k g})\end{array}$ & $\begin{array}{l}\text { Average Total } \\
\text { fertilizer/yr } \\
(\mathbf{k g})^{\mathbf{1}}\end{array}$ & $\begin{array}{l}\text { CFEn (nuts/ } \\
\text { Kg fertilizer } \\
\text { Applied }\end{array}$ & $\begin{array}{l}\text { CFEc (kg } \\
\text { copra/ kg } \\
\text { fertilizer } \\
\text { applied }\end{array}$ \\
\hline & & & & & \\
\hline MLYD & 130 & 24.3 & 4.40 & 29.5 & 5.52 \\
\hline CATGD & 72 & 15.9 & 4.34 & 16.6 & 3.66 \\
\hline TACGD & 85 & 19.0 & 4.36 & 19.5 & 4.34 \\
\hline & & & & & \\
\hline
\end{tabular}

' average fertilizers applied ( $\mathrm{kg} /$ treelyear):

MLYD - $1.3 \mathrm{~kg}$ Ammo. sulfate $+1.62 \mathrm{~kg} \mathrm{NaCl}+0.30 \mathrm{~kg} \mathrm{KCl}+1.10 \mathrm{~kg}$ dolomite $+40 \mathrm{~g}$ borax; CATGD $-1.40 \mathrm{~kg}$ Ammo. sulfate $+1.48 \mathrm{~kg} \mathrm{NaCl}+0.25 \mathrm{~kg} \mathrm{KCl}+$ $1.20 \mathrm{~kg}$ dolomite $+40 \mathrm{~g}$ borax; TACGD $-1.39 \mathrm{~kg}$ Ammo.sulfate $+1.47 \mathrm{~kg} \mathrm{NaCl}$ $+0.30 \mathrm{~kg} \mathrm{KCl}+1.20$ dolomite $+42 \mathrm{~g}$ borax .

Looking at the fertilizer use efficiency in terms of the crop fertilizer use index (CFE), measured by coconut yield per $\mathrm{kg}$ fertilizer applied(Magat, 1966), i.e. CFEn (nut yield/tree/ year) and CFEc (copra yield/tree/yr), this is presented in table 1.2. It shows that the MLYD achieved the highest (both in nut and copra yields) at 29.5 nuts and $5.52 \mathrm{~kg}$ copra per $\mathrm{kg}$ fertilizer applied, followed by the TACD with 19.5 CFEn and 4.35 CFEc and that of CATGD with 16.6 CFEn and 3.66 CFEc.

Earlier, the CFE index was tested in the country, using the performance of several hybrids and local talls in a nationwide coconut coconuts as guide-reference in the nutritional (foliar) diagnosis of the crop. In many cases, critical levels of growth or yield-limiting nutrient(s) of coconut are determined using field data on yield and leaf nutrients, either from an extensive survey or fertilizer/nutrient response studies (usually at increasing rates of a limiting or deficient nutrient (s) in representatives coconut areas. Statistical or biometrical analysis of data as ANOVA, correlation and regression analysis, and trend analysis are used to identify critical levels leaf nutrient in relation with growth and yield data obtained from designed long-term experiments (Magat, 1998). 
Clearly, the average (or adequacy levels) leaf nutrient concentrations of dwarf varieties: (1) Catigan green dwarf (CATGD) and (2) Tacunan green dwarf (TACGD) are higher (slight to moderate degree) compared to that of Malayan yellow dwarf (MLYD), except in leaf $\mathrm{Mg}$ and $\mathrm{S}$.

Table 2 indicates that the average (1995 -1999) leaf nutrient concentrations (levels) of sampled leaf No.14 of dwarfs were not statistically different in terms of leaf nutrients $\mathrm{N}, \mathrm{P}, \mathrm{Ca}, \mathrm{S}$, and $\mathrm{B}$. In contrast, these significantly vary in leaf $\mathrm{K}$ (green dwarfs > MLYD); leaf Mg (MLYD > green dwarfs); leaf $\mathrm{Na}$ (green dwarfs> MLYD); and Leaf $\mathrm{Cl}$ ( consistent in almost all years, with the highest levels in MLGD. Moreover, leaf $\mathrm{Cl}$ trends showed clear consistency, with CATGD having the highest level in all years, except in 1998.

\subsection{Adequacy (normal) and Critical Levels of Leaf Nutrients}

Table 3 below shows an estimate or approximation of the normal or average levels of leaf nutrients for the adequacy levels and the critical levels of mature and bearing dwarf coconut variety. The estimation of adequacy levels is based from the mean of the three varieties evaluated, while the leaf nutrient critical levels was derived by assuming that

\begin{tabular}{|c|c|c|c|c|c|c|c|c|c|}
\hline \multicolumn{10}{|c|}{$\begin{array}{l}\text { TABLE 2. LEAF NUTRIENT LEVELS OF } 3 \text { DWARF VARIETIES AT PCA-ZRC, } \\
\text { ZAMBOANGA CITY (LEAF RANK } \# 14,1995-1999) .\end{array}$} \\
\hline \multirow{2}{*}{ Variety } & \multicolumn{9}{|c|}{ Leaf Nutrient (\% dry matter, leaf rank \# 14) } \\
\hline & $\mathrm{N}$ & $\mathrm{P}$ & $\mathrm{K}$ & $\mathrm{Ca}$ & $\mathrm{Mg}$ & $\mathrm{Na}$ & $\mathrm{Cl}$ & $\mathrm{S}$ & Bppm \\
\hline MLYD & 1.82 & 0.138 & $0.81 \mathrm{~b}$ & 0.39 & $0.33 \mathrm{a}$ & $0.18 \mathrm{a}$ & $0.30 \mathrm{~b}$ & 0.18 & 13.0 \\
\hline CATGD & 1.88 & 0.148 & $1.10 \mathrm{a}$ & 0.46 & $0.27 \mathrm{~b}$ & $0.11 \mathrm{~b}$ & $0.52 \mathrm{a}$ & 0.17 & 12.0 \\
\hline TACGD & 1.82 & 0.131 & $1.09 \mathrm{a}$ & 0.42 & $0.25 \mathrm{~b}$ & $0.12 \mathrm{~b}$ & $0.41 \mathrm{ab}$ & 0.17 & 13.2 \\
\hline Stat. Sign. & ns & Ns & $* *$ & Ns & $*$ & $* *$ & $*$ & $\mathrm{~ns}$ & ns \\
\hline C.V. $(\%)$ & 9.7 & 7.9 & 8.5 & 12.0 & 9.9 & 16.7 & 22.3 & 13.4 & 8.8 \\
\hline \multicolumn{10}{|c|}{$\begin{array}{l}\text { ns - Not significant } \\
* \text { Significant at } 5 \% \text { level } \\
* * \text { Highly significant at } 1 \% \text { level }\end{array}$} \\
\hline
\end{tabular}

CATGD similar to TACGD but > MLGD). This suggests that uptakes or concentrations of leaf nutrients $\mathrm{K}, \mathrm{Mg}, \mathrm{Na}$ and $\mathrm{Cl}$ are likely variety-sensitive, while the rest (leaf $\mathrm{N}, \mathrm{P}, \mathrm{Ca}, \mathrm{S}$ and B) are not.

Looking closely on the trends (19951999, with values in 1997 not included) of leaf nutrient contents as indicated in figures 1-99), the following are noted. For leaf $\mathrm{K}$, the trend is almost consistent, except for year 1996 (TACGD had the highest content), while in most years CATGD had the highest leaf $\mathrm{K}$ level. For leaf $\mathrm{Mg}$ and $\mathrm{Na}$, the trend were critical level is very likely about $10 \%$ lower in nutrient

concentration than that of the adequacy level of nutrients in leaves of coconut. Generally, the leaf nutrient critical level refers to the concentration in plant tissues as in a particular leaf position in the plant (leaf rank \#14 for mature coconuts), of which a positive growth or economic yield response to fertilizer application (to supply one or more plant nutrients) is very likely, as critical concentration of nutrient(s) is considered growth- or yield-limiting. 
To optimize growth and yield of coconuts (talls, hybrids and dwarfs), crop nutrients should not be yield-limiting or the crop must have adequate and balanced nutrition (macro and micro-nutrients) in timely and of dwarf variety, indicated by the author for the first time in this paper.

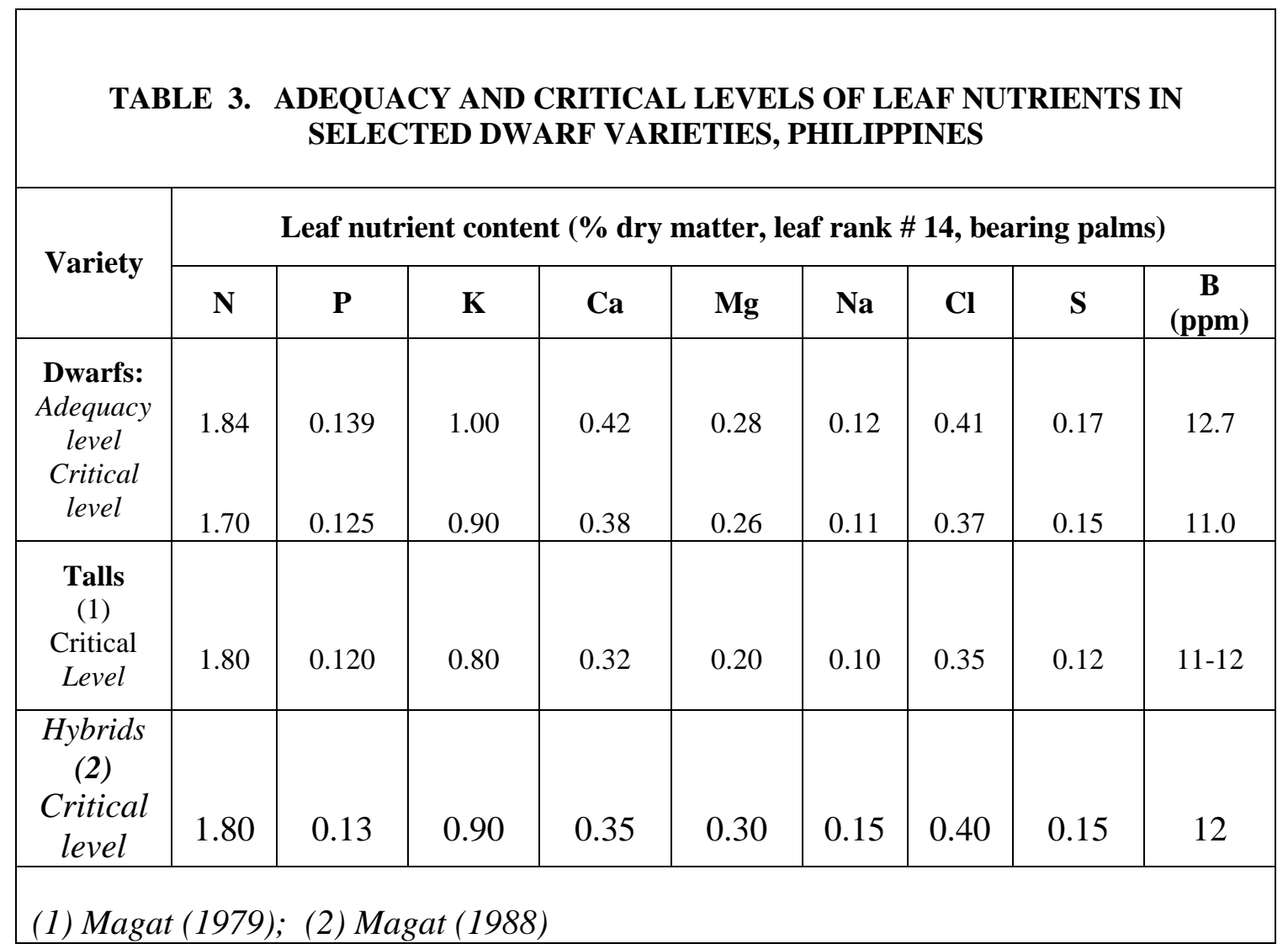

sustained manner. Hence, the importance of at least an annual crop nutrition monitoring to check the undesirable inadequate and imbalanced nutrition of palms.

In bearing palms (based on leaf rank \#14), the average leaf nutrient critical levels of dwarfs strongly appears slightly higher than talls, except for leaf nitrogen (dwarfs, $1.70 \%$ vs talls, $1.80 \%$ ). However, leaf nutrient critical levels of hybrids (earlier presented by the author in 1988) are generally slightly higher than that 

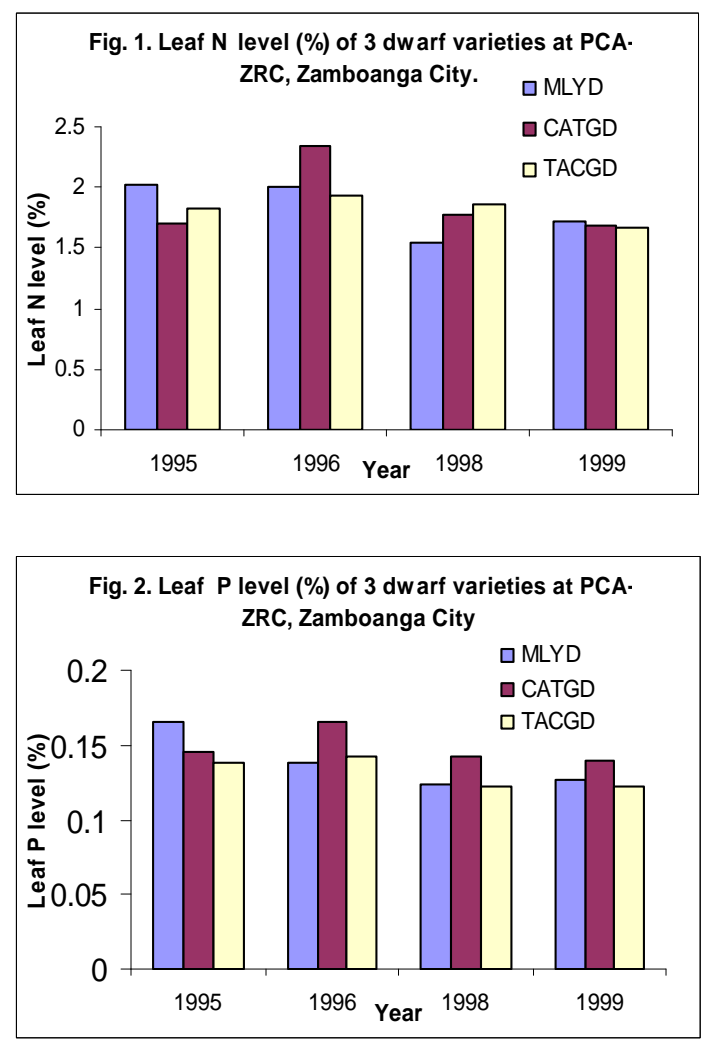

Fig. 3. Leaf $\mathrm{K}$ level (\%) of $3 \mathrm{dw}$ arf varieties at PCAZRC, Zamboanga City.

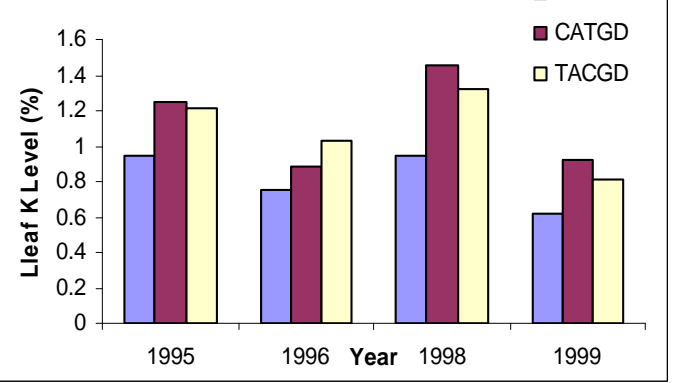

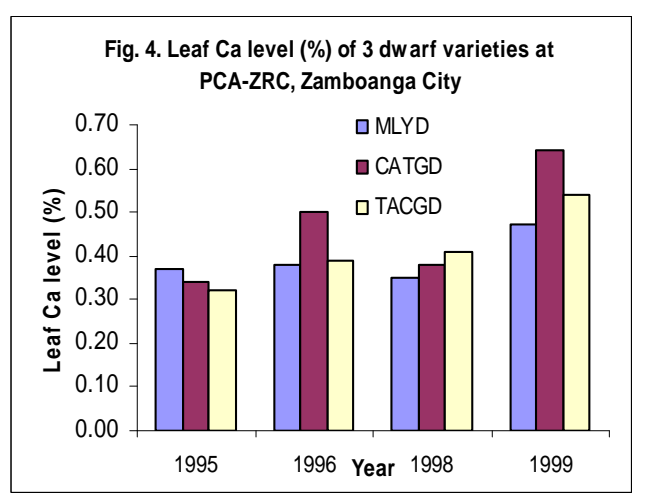
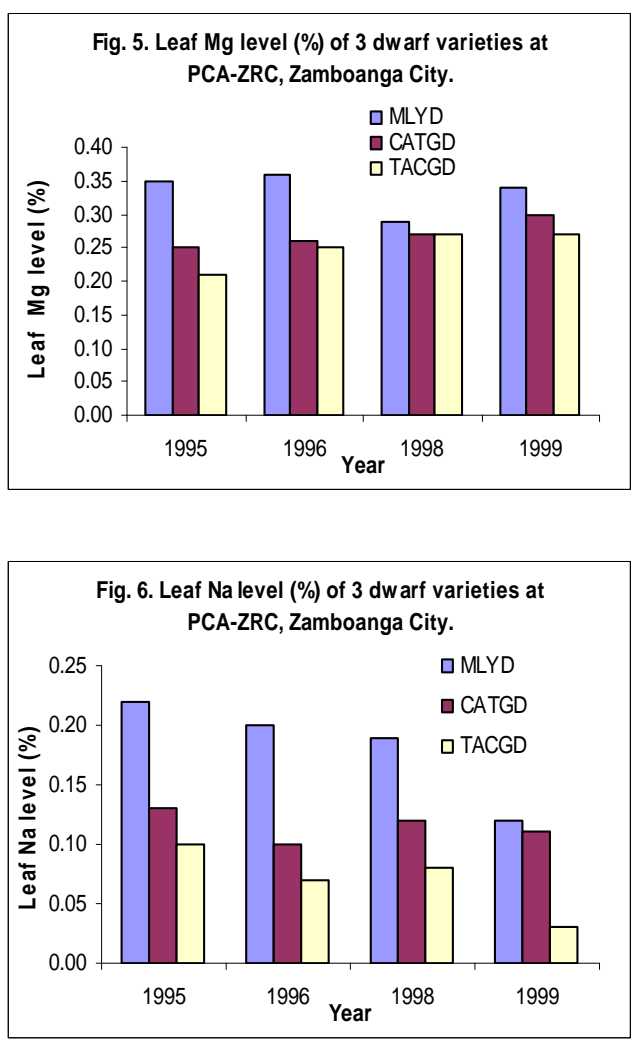


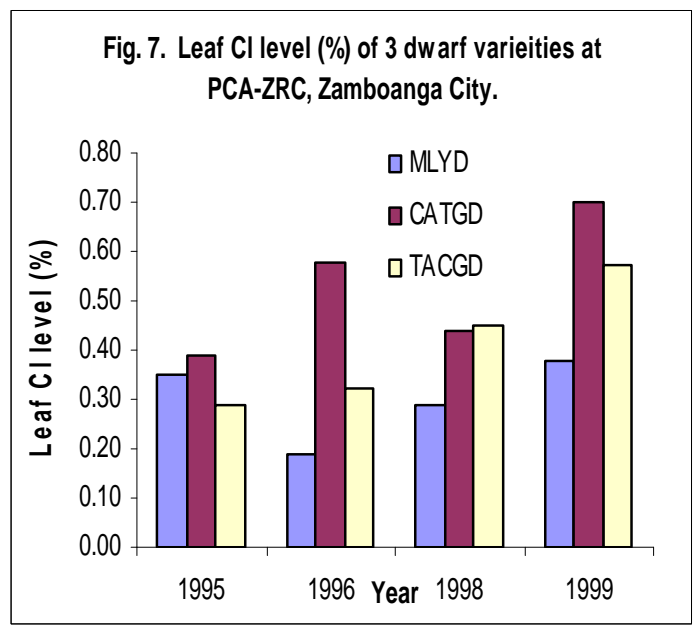

Fig. 8. Leaf $S$ level (\%) of $3 \mathrm{dw}$ arf varieties at PCAZRC. Zamboanga City.

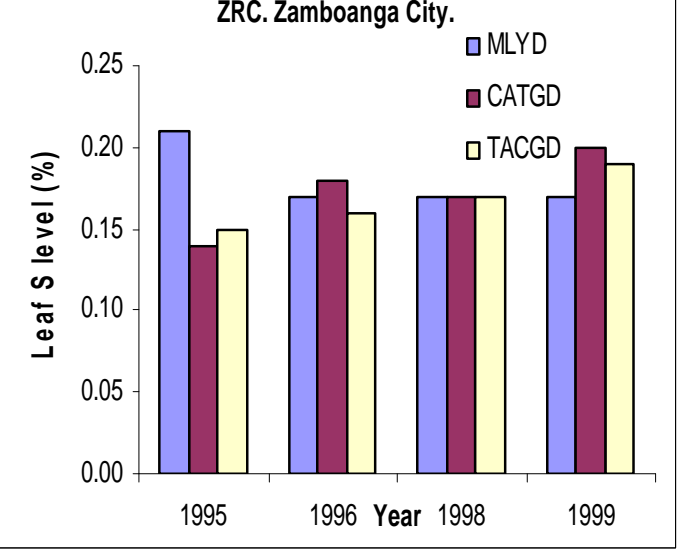

Fig. 9. Leaf $B$ level (ppm) of $3 \mathrm{dwarf}$ varieties at PCA-ZRC, Zamboanga City

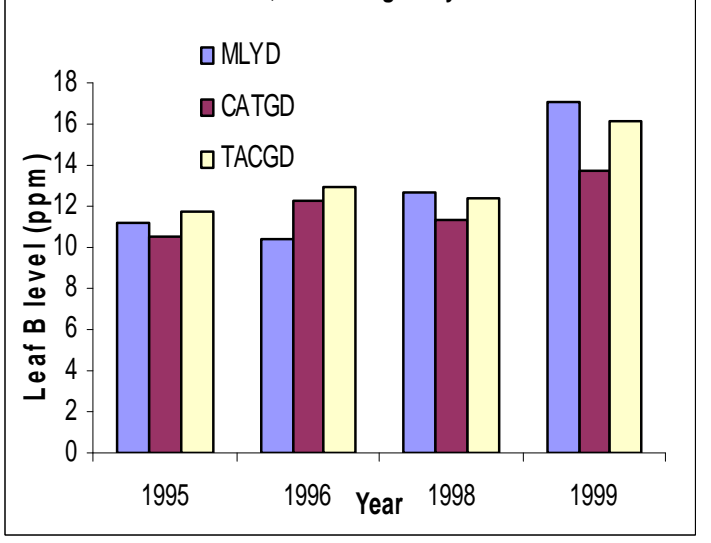

\section{CONCLUSION}

In the absence of extensive field data on yield and associated leaf nutrient contents of dwarf coconut varieties or designed field experiments (testing one or more deficient nutrients) in identified nutrient-deficient area(s), an available historical record (at least three years) of the leaf nutrient concentrations of productive plantings or experimental blocks may be used to determine an average or normal (adequacy) levels leaf nutrients as N, P, K, Ca, $\mathrm{Mg}$. Na, $\mathrm{Cl}, \mathrm{S}$ and $\mathrm{B}$. The critical levels, values of which are likely 10-20\% lower than the adequacy level of leaf nutrients (leaf rank\#14, bearing palms) may be estimated.

Using the substantial data gathered from the dwarf varieties (particularly MLYD, CATGD and TACGD) at the PCA-ZRC (1995 1999), a simple averaging (to explore practical tendencies of data) revealed: it appears that the physiological adequacy and critical leaf nutrient levels of the yellow dwarf and green dwarf varieties differs (slightly to moderately) in most nutrients. Generally, leaf nutrient levels of dwarfs are slightly higher than that of talls, but lower than hybrid coconuts.

For bearing dwarfs in general, a reference or guide on leaf nutrient critical levels (leaf rank \#14) as derived in this study is presented, as follows: $1.70 \% \mathrm{~N}, 0.125 \% \mathrm{P}$, $0.90 \% \mathrm{~K}, 0.38 \% \mathrm{Ca}, 0.26 \% \mathrm{Mg}, 0.12 \% \mathrm{Na}, 0.37$ $\% \mathrm{Cl}, 0.15 \% \mathrm{~S}$ and $11 \mathrm{ppm}$ boron (B).

Nevertheless, with the initial findings that the normal or adequacy levels of some leaf nutrients of dwarf varieties tend to differ, particularly leaf $\mathrm{K}, \mathrm{Mg}, \mathrm{Na}$, and $\mathrm{Cl}$, future refinements of physiological leaf critical levels should be considered specific to the different dwarf varieties. 
With the availability of leaf analysis results of highly productive dwarf varieties of coconut for several cropping years, it is possible to determine the acceptable adequate levels of leaf nutrients to derive the average physiological critical levels The estimated critical levels of leaf nutrients of dwarf varieties of coconut may be based on the estimated adequacy or average values of leaf nutrient levels as presented in this work. To confirm or validate the critical levels indicated in this work, further works on dwarf varieties of coconuts - particularly on salient aspects of crop mineral nutrition cum experimentally - designed fertilization response studies under different cases of soil mineral nutrient deficiencies in coconut areas should be actively pursued at different stages of the growth and development dwarfs.

\section{ACKNOWLEDGEMENT}

The author extends his profound gratitude to Department Manager Gerardo A. Santos, Center Manager, and Mr. Ramon L. Rivera, Sr. Science Research Specialist \& Officer-inCharge, Breeding and Genetics Division, PCAZamboanga Research Center (San Ramon, Zamboanga City), for the cooperation extended in reviewing the historical data of the three dwarf populations blocks grown at the Center;

Special thanks to Ms Millicent I. Secretaria, Scientist I, Agronomy and Soils Division, Davao Research Center (BagoOshiro, Davao City) - the R\&D institution of which the author is closely scientifically affiliated, for her prompt assistance in the biometrical analysis/ partial computerization of the data;

And likewise, his special appreciation to the Plant Tissue Analysis Laboratory, RDEB, Philippine Coconut Authority, Central Office, Diliman, Quezon City, Metro Manila, for the timely services in the analyses of coconut leaf samples used in this work.

\section{REFERENCES}

Balingasa E.N. and G. A. Santos. (1978). Germination characteristics of F1 coconut hybrids. Phillip. J. Coconut Studies 3(1): 29 -36 .

Eyzaguirre, P.B. (1998). Farmers's contribution to improving the value and uses of coconut through the maintenance and use of genetic diversity. In: Batugal, P.A., V. Ramanatha Rao and C. Bong (Editors). Promoting Multi-purpose Uses and Competitiveness of the Coconut. Proceedings of a workshop, 26-29 September 1996, Chumpon, Thailand. IPGRI-APO, Serdang, Malaysia.

Kamaruddin Wazir, S. and A. Othman, (1998). Potential for young tender coconuts and requirements for germplasm conservation and varietal development. In: Batugal, P.A., Ramanatha Rao and C. Bong (Editors). Promoting Multi-purpose Uses and Competitiveness of the Coconut. Proceedings of a workshop, 26-29 September 1996, Chumphon, Thailand. IPGRI-APO, Serdang, Malaysia.

Magat, S. S. (1998). Determining nutritional status and fertilizer recommendation for coconut. R\&D Technical Report No.5. Agricultural Research and Development Branch, Philippine Coconut Authority, Diliman, Quezon City. 87p.

Magat, S. S. (1999). Handbook on Fertilizer Recommendation for Coconut and Selected Intercrops. The Asian and Pacific Coconut Community. Djakarta, Indonesia. 106p.

Magat, S.S. (1996). Crop fertilizer use efficiency analysis (CFE): A tool in agroclimatic conditions. Coconut Research and Development J. (APCC) 7(2): 1-33.

Magat, S.S., Alforja, L.M. and Oguis, L.G. (1989). An estimation of the critical and optimum levels of leaf-chlorine in bearing coconuts. A guide for foliar diagnosis. Phil. J. Coco. Studies 13(1) 6-9. 
Manciot, R., Ollagnier M. and Ochs, R. (1979). Mineral nutrition and fertilization of coconuts around the world. Oleagineux 34(11): 499-515; 34: 563-579.

Naka, P. (1998). Potential of producing sugar from coconut and requirements for germplasm conservation and varietal development. In: Batugal P.A., Ramanatha Rao and C.Bong (Editors). Promoting Multi-purpose Uses and Competitiveness of Coconut. Proceedings of a workshop, 26-29 September 1996, Chumphon, Thailand. IPGRI-APO, Serdang, Malaysia.

Novarianto, H. and G.A. Santos (1998). Varietal preferences of coconut farmers and processors and proposed conservation and breeding strategies in Southeast Asia. In: Batugal, P.A., Ramanatha Rao and C. Bong (Editors). Proceseedings of a workshop, 2629 September 1996, Chumphon, Thailand. IPGRI-APO, Serdang, Malaysia.

Ohler, J.G. and Magat, S.S. (2001). Cocos nucifera L. In: van der Vossen, H.A.M. and Umali, B.E. (Editors): Plant Resources of South_East Asia No.14. Vegetable oils and fats. Backhuys Publishers, leiden, the Netherlands. pp. $76-84$.

Ovasuru, T. (1998). Problems and opportunities of PNG farmers related to coconutvarieties. In: Batugal, P.A., Ramanatha Rao and C. Bong (Editors). Promoting Multi-purpose Uses and Com-petitiveness of the Coconut. Proceedings of a workshop, 26-29 September 1996, Chumphon, Thailand. IFGRI-APO, Serdang, Malaysia.

Peries, R.R.A. (1998). Coconut varieties for industrial processing and domestic uses: Germplasm conservation and breeding strategies : Sri Lankan experience. In: Batugal, P.A., Ramanatha Rao and C. Bong (Editors). Promoting Multi-purpose Uses and Com-petitiveness of the Coconut. Proceedings of a workshop, 26-29 September 1996, Chumphon, Thailand. IFGRI- APO, Serdang, Malaysia.
Santos, G.A. (1989). Regional Testing of Promising Coconut Hybrids and Cultivars (MULTILOC). Progress Repot, Philippine Coconut Authority. 24 p.

Thampan, P.K. (1998). Suitable varieties of coconut for household use and local markets. In: Batugal, P.A., Ramanatha Rao and C. Bong (Editors). Promoting Multipurpose Uses of the Coconut. Proceedings of a workshop, 26-29 September 1996, Chumphon, Thailand. IPGRI-APO, Serdang, Malaysia. 